\title{
PERANCANGAN TOPOLOGI DINAMIS SECARA ACAK DALAM MOBILE AD- HOC NETWORK DENGAN PENDEKATAN PEMODELAN
}

\author{
S.N.M.P. Simamora \\ Sekolah Teknik Elektro dan Informatika \\ Institut Teknologi Bandung \\ Email: snmpsimamora@students.itb.ac.id
}

\begin{abstract}
ABSTRAK
Mobile Ad-hoc Network (MANET) sebagai wireless local area network yang bersifat dinamis dalam hal pergerakan node berperan untuk mengkondisikan setiap terminal client sebagai backwarding/fowarding-devices. Dengan demikian kondisi topologi jaringan akan berubah seiring dengan perubahan posisi pada node-client. Hal ini tentu saja akan memberikan keuntungan yang baik pada client dalam segi fleksibilitas tempat, mengurangi biaya instalasi, reduksi penyediaan infrastruktur dan sifat temporary instalasi sesuai dengan kebutuhan yang diinginkan. Pada penelitian ini telah dilakukan pemodelan dan simulasi untuk menunjukkan algoritma routing-network, status node yang terlibat dalam MANET, dan perhitungan nilai QoS dari komunikasi-data yang dibangun antar node yang saling bertetangga. Hasilnya menunjukkan perubahan topologi jaringan mengalami perubahan seiring dengan perubahan skenario yang dibangkitkan secara random dan stokastik; dan perubahan topologi jaringan ini merepresentasikan perubahan posisi node dalam MANET saat membangun komunikasi-data dari node-sender ke node-receiver. Metode pengujian menggunakan teknik kuantitatif serta kondisi random direpresentasikan dengan pembangkitan bilangan random yang bekerja berdasar Distribusi Normal/Gauss. Algoritma SNetS yang digunakan telah dapat mengakomodir jumlah N-node, sehingga kondisi node-terminal, bagaimana status node, serta QoS yang didapatkan mendekati kondisi real.
\end{abstract}

Kata kunci: mobile ad-hoc network, backwarding/fowarding-devices, model, topologi dinamis, random, algoritma SNetS.

\begin{abstract}
Mobile Ad-hoc Network (MANET) as a wireless local area network that is dynamic in terms of node movement to condition each client terminal acts as a backwarding/fowarding-devices. Thus the condition of the network topology will change with a change in position on the client node. This course will give you a good profit on the client in terms of flexibility of place, reducing installation costs, the reduction of the provision of infrastructure and temporary nature of the installation in accordance with the requirements. This research has been carried out modeling and simulation to show routing-network algorithm, node status involved in MANET, and the calculation of the of data communication QoS value built between nodes that are neighbors. The results show the changes of network topology has changes along with the scenarios changes randomly and stochastic generated; and the changes in the network topology represents a change in position of nodes in MANET while data communication was built from node-sender to node-receiver. The testing method using quantitative techniques and random conditions represented by the generation of random numbers that work based on the Normal/Gauss Distribution. A SNetS algorithm used has been able to accommodate the number of $N$-node, so how the node-terminal conditions, how the status of nodes, as well as QoS obtained close to real conditions.
\end{abstract}

Keywords: mobile ad-hoc network, backwarding/fowarding-devices, model, dynamic-topology, random, SNetS algorithm.

\section{PENDAHULUAN}

Mobile Ad-Hoc Network (MANET) merupakan suatu jaringan wireless dengan topologi dinamis [1][2] dengan mengalih-fungsikan setiap terminal host-computer client menjadi backwarding/fowarding-devices seperti halnya fungsi sebagai access-point [3][4]. MANET menerapkan klasifikasi topologi jaringan point-to-point atau adhoc sebagai basis infrastruktur jaringan saat membangun sebuah jaringan komunikasi data. Oleh sebab dimodelkan sebagai point-to-point menyebabkan MANET lebih tepat digolongkan dalam jenis mesh-network [5][6]. Dan pada MANET, pengalamatan yang digunakan tidak bergantung pada kategori static-IP maupun dynamic-IP [3][4][7]. Peranan MANET yang terpenting adalah dapat menyediakan infrastruktur jaringan telekomunikasi secara sementara dan dinamis dalam kondisi darurat maupun oleh alasan ketersediaan infrastruktur fisik yang tidak memadai [8][9]. 
Setiap terminal host-computer dapat membangun komunikasi data dari setiap posisinya dalam jaringan wireless sepanjang dalam jangkauan line-of-sight antar node-node client. Hal ini menunjukkan bahwa topologi jaringan wireless yang terbentuk dalam MANET menjadi bersifat dinamis; oleh sebab menyesuaikan dengan perpindahan setiap host-computer [10][11].

Seperti halnya pada terminal umum lainnya dalam jaringan wireless, bahwa routing packet-data akan diteruskan pada node-node tetangga yang relatif saling berdekatan. Sehingga pada MANET, dengan ditiadakannya access-point yang berperan sebagai backwarding/fowarding-devices, packet-data akan diteruskan pada node-node yang saling bertetangga menuju pada node atau terminal tujuan [2][10][12]. Ditunjukkan pada Gambar 1 node-A berperan sebagai backwarding/fowarding-devices untuk meneruskan packet-data dari node-pengirim menuju nodepenerima; sedangkan pada Gambar.1.b menjelaskan oleh sebab posisi node-sender dan node-receiver relatif tidak cukup saling berdekatan untuk membangun komunikasi-data maka node-A dan node-B berperan sebagai backwarding/fowarding-devices dalam me-routing-kan packet-data. Kondisi inilah disebut dengan lintasan two's ring oleh sebab packet-data di-routing-kan dua lompatan untuk menuju node-receiver [13][14].

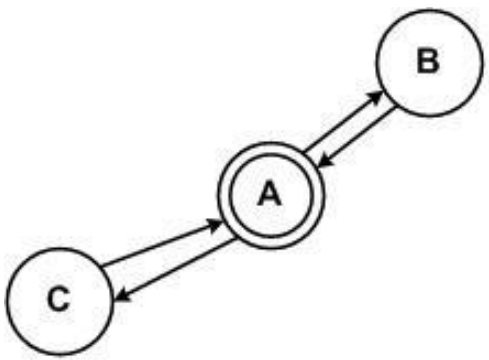

a) one's ring

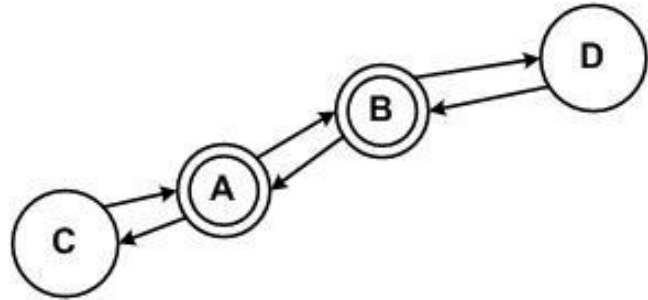

b) two's ring

\section{Gambar 1. Skema Mobile Ad-hoc Network}

Pemodelan jaringan komputer dengan menggunakan metode graph telah umum digunakan [13][15][16] untuk menentukan optimum-cost dari transportasi rute jaringan yang dibangun saat suatu packet-data dikirimkan melewati node-node dalam jaringan yang saling bertetangga. Tujuannya untuk mendapatkan algoritma routing network yang optimal saat posisi setiap node menentukan dan berpengaruh pada peta routing packet-data yang dikirimkan dari node-sender menuju node-receiver [17][18].

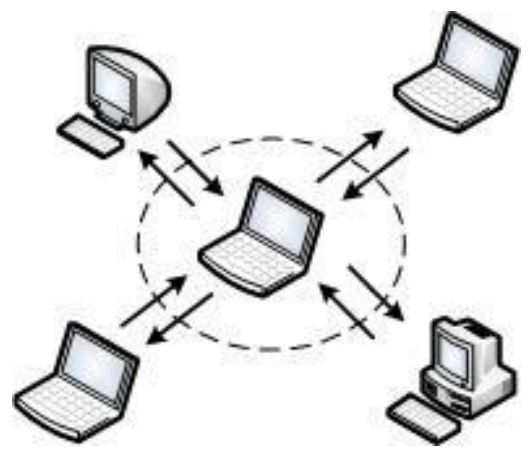

Gambar 2. Model Mobile Ad-hoc Network

Dari sejumlah penelitian yang telah dilakukan [2][3][4][7], MANET yang dibangun masih sebatas one's ring seperti ditunjukkan pada Gambar .2, dimana node-client berperan sebagai pusat pembagi sambungan di antara jumlah client yang terbangun dalam MANET. Dan pada penelitian ini dibahas perihal mekanisme perancangan topologi dinamis secara acak untuk membentuk MANET dengan pendekatan pemodelan; dan teknik graph digunakan sebagai metode pemodelan sebagai dasar metode kuantitatifnya.

\section{METODE}

Metode pemodelan yang digunakan adalah analitik dan komputerisasi dengan berbasiskan teknik graph. MATLAB digunakan untuk dukungan simulasi saat metode analitik yang telah disusun berbasiskan algoritma simulasi jaringan MANET, disebut SNetS Algorithm, yang digunakan. Untuk membangkitkan kondisi acak, digunakan Distribusi Normal/Gauss dalam algoritma yang diajukan dan dibangun. 
Setiap komunikasi data yang dibangun antara dua node disebut dengan path; dan setiap node dalam jaringan komputer walaupun dalam keadaan ON namun belum tentu status on-line. QoS diukur dalam tiga parameter yakni: end-to-end delay (semakin baik apabila nilai semakin kecil), throughput (semakin baik apabila nilai semakin besar), dan packet-loss (nilai semakin baik apabila nilai mendekati 0). Dua node, misalkan node-X dan node-Y, jika memiliki nilai bobot dalam routing packet-data, $\forall$ (weight-cost), maka $\forall_{X Y}$ relatif terhadap $\forall_{Y X}$. Kondisi ini menunjukkan tidak berlaku sifat komutatif [11][13][19]. Pada penelitian ini dipilih $\forall_{\mathrm{XY}}$ (atau $\forall_{\mathrm{YX}}$ ) terbesar yang merujuk pada nilai throughput, dengan alasan throughput kanal data terdeteksi terlebih dahulu sebelum sebuah packet-data dikirimkan bila dibandingkan end-to-end delay dan packet-loss. berikut:

Pada pemodelan yang dilakukan, tahapan algoritma dibagi dalam lima langkah, yakni sebagai Tahap-1: Menentukan Tabel Acuan, yang terdiri dari path-node, path-cost (sebagai acuan QoS), kriteria status connected suatu path antar-node

Jika $\Sigma$ (node) dalam MANET $=\mathrm{N}$, maka

total_path-node (i) $=\mathrm{NxN}-\mathrm{N}$

Pada penelitian ini digunakan lima node, maka total path-node yang dapat dibangun ditunjukkan pada Tabel 1.

Tabel 1. Acuan path-node

\begin{tabular}{|c|c|c|c|c|c|}
\hline i & range & path & $\mathrm{i}$ & range & path \\
\hline 1 & $0 \leq \operatorname{rand}()<0.05$ & A-B & 11 & $0.50 \leq \operatorname{rand}()<0.55$ & C-D \\
\hline 2 & $0.05 \leq \operatorname{rand}()<0.10$ & A-C & 12 & $0.55 \leq \operatorname{rand}()<0.60$ & C-E \\
\hline 3 & $0.10 \leq \operatorname{rand}()<0.15$ & A-D & 13 & $0.60 \leq \operatorname{rand}()<0.65$ & D-A \\
\hline 4 & $0.15 \leq \operatorname{rand}()<0.20$ & A-E & 14 & $0.65 \leq \operatorname{rand}()<0.70$ & D-B \\
\hline 5 & $0.20 \leq \operatorname{rand}()<0.25$ & B-A & 15 & $0.70 \leq \operatorname{rand}()<0.75$ & D-C \\
\hline 6 & $0.25 \leq \operatorname{rand}()<0.30$ & $\mathrm{~B}-\mathrm{C}$ & 16 & $0.75 \leq \operatorname{rand}()<0.80$ & D-E \\
\hline 7 & $0.30 \leq \operatorname{rand}()<0.35$ & B-D & 17 & $0.80 \leq \operatorname{rand}()<0.85$ & E-A \\
\hline 8 & $0.35 \leq \operatorname{rand}()<0.40$ & B-E & 18 & $0.85 \leq \operatorname{rand}()<0.90$ & E-B \\
\hline 9 & $0.40 \leq \operatorname{rand}()<0.45$ & $\mathrm{C}-\mathrm{A}$ & 19 & $0.90 \leq \operatorname{rand}()<0.95$ & E-C \\
\hline 10 & $0.45 \leq \operatorname{rand}()<0.50$ & C-B & 20 & $0.95 \leq \operatorname{rand}()<1.0$ & E-D \\
\hline
\end{tabular}

Jika nilai $\forall$ dibagi secara berjenjang dari 1 sampai dengan 10, maka dengan membangun domain kemunculan nilai berdasar range (rentang) bilangan random ditunjukkan pada Tabel 2.

Tabel 2. Acuan path-cost $(\forall)$

\begin{tabular}{|c|c|c|c|}
\hline range & $\forall$ & range & $\forall$ \\
\hline $0.0 \leq \operatorname{rand}()<0.1$ & 1 & $0.5 \leq \operatorname{rand}()<0.6$ & 6 \\
\hline $0.1 \leq \operatorname{rand}()<0.2$ & 2 & $0.6 \leq \operatorname{rand}()<0.7$ & 7 \\
\hline $0.2 \leq \operatorname{rand}()<0.3$ & 3 & $0.7 \leq \operatorname{rand}()<0.8$ & 8 \\
\hline $0.3 \leq \operatorname{rand}()<0.4$ & 4 & $0.8 \leq \operatorname{rand}()<0.9$ & 9 \\
\hline $0.4 \leq \operatorname{rand}()<0.5$ & 5 & $0.9 \leq \operatorname{rand}()<1.0$ & 10 \\
\hline
\end{tabular}

Algoritma menetapkan status connected suatu path-node:

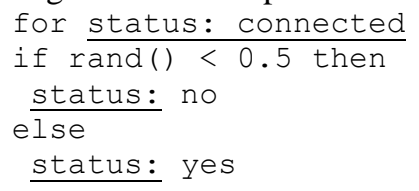

Tahap-2: Memunculkan iterasi percobaan minimal 10 kali dari kondisi randomize yang didapatkan menggunakan bilangan random yang bekerja berdasar Distribusi Normal/Gauss.

Tahap-3: Memunculkan posisi setiap node pada kurva-X (absis) dan kurva-Y (ordinat) dimana masingmasing dilakukan secara randomize, dengan syarat: apabila muncul nilai koordinat dua node atau lebih, maka nilai absis dan ordinat tersebut diiterasi kembali sampai didapatkan berbeda.

Formula yang digunakan:

untuk nilai absis maupun ordinat:

$\mathrm{x}^{\prime}$ or $\mathrm{y}^{\prime} \leftarrow$ \{rand() roundup $1^{\prime}$ digit

$\mathrm{x} \leftarrow \mathrm{x}^{\prime} \star 10$

$\mathrm{y} \leftarrow \mathrm{y}^{\prime} \star 10$; 
Tahap-4: Gambarkan posisi setiap node dalam kurva sumbu-X terhadap sumbu-Y. Path-node yang digambarkan pada MANET mengikuti syarat dan batasan sebagai berikut:

a) jika ditemukan dua atau lebih path-node yang sama pada iterasi yang dilakukan, maka pilih path-node dengan iterasi terbaru

b) status connected pada path-node dengan nilai: tidak, deskripsikan dengan style='dash'

c) tidak berlaku sifat komutatif pada path-node; $v(\mathrm{~A}, \mathrm{~B})$ berbeda dengan $v(\mathrm{~B}, \mathrm{~A})$

d) apabila ditemukan koordinat $(\mathrm{x}, \mathrm{y})$ dua node atau lebih yang sama, maka lakukan iterasi kembali sampai didapatkan tidak ada yang sama

\section{HASIL DAN PEMBAHASAN}

Pada penelitian ini dilakukan 10 kali iterasi untuk setiap langkah dan tahapan dengan Algoritma SNetS, dimana dilakukan dalam 4 kali percobaan. Hal ini menunjukkan nantinya ada empat topologi dengan lima node, yakni: A,B,C,D,E, yang berbeda bersifat dinamis.

Apabila diasumsikan keempat topologi ini merupakan perubahan state perpindahan posisi masingmasing node dari kelima workstation host-computer dalam MANET tersebut, maka terlihat hasilnya nanti bagaimana kelebihan MANET dapat menerapkan proses komunikasi data yang dinamis dan fleksibel.

Percobaan untuk simulasi-1 ditunjukkan pada Tabel 3 sampai dengan 6; percobaan untuk simulasi-2 ditunjukkan pada Tabel 7 sampai dengan 10; dan percobaan untuk simulasi-3 serta terakhir simulasi-4 ditunjukkan pada Tabel 11 sampai dengan 14.

Tabel 3. Simulasi-1: path-node

\begin{tabular}{ccc}
\hline $\mathrm{i}$ & rand () & path-node \\
\hline 1 & $\mathbf{0 . 0 1 3 5 5 7 4 4 4}$ & A-B \\
\hline 2 & $\mathbf{0 . 7 1 6 9 7 7 0 8 8}$ & D-C \\
\hline 3 & $\mathbf{0 . 8 6 9 2 4 5 0 7 9}$ & E-B \\
\hline 4 & $\mathbf{0 . 1 3 8 4 2 3 7 8 3}$ & A-D \\
\hline 5 & $\mathbf{0 . 8 7 2 0 6 7 7 1 6}$ & E-B \\
\hline 6 & $\mathbf{0 . 9 7 4 2 8 1 3 5 1}$ & E-D \\
\hline 7 & $\mathbf{0 . 2 0 9 0 8 3 4 8 7}$ & B-A \\
\hline 8 & $\mathbf{0 . 5 4 2 0 9 2 1 5 8}$ & C-D \\
\hline 9 & $\mathbf{0 . 2 3 9 5 7 7 1 1 8}$ & B-A \\
\hline 10 & $\mathbf{0 . 0 2 0 7 3 2 9 3 9}$ & A-B
\end{tabular}

Tabel 4. Simulasi-1: path-cost node

\begin{tabular}{cccc}
\hline $\mathrm{i}$ & path-node & $\operatorname{rand}()$ & $\forall$ \\
\hline 1 & A-B & $\mathbf{0 . 0 1 3 5 5 7 4 4 4}$ & $\mathbf{1 0}$ \\
\hline 2 & D-C & $\mathbf{0 . 7 1 6 9 7 7 0 8 8}$ & $\mathbf{6}$ \\
\hline 3 & E-B & $\mathbf{0 . 8 6 9 2 4 5 0 7 9}$ & $\mathbf{1}$ \\
\hline 4 & A-D & $\mathbf{0 . 1 3 8 4 2 3 7 8 3}$ & $\mathbf{1 0}$ \\
\hline 5 & E-B & $\mathbf{0 . 8 7 2 0 6 7 7 1 6}$ & $\mathbf{9}$ \\
\hline 6 & E-D & $\mathbf{0 . 9 7 4 2 8 1 3 5 1}$ & $\mathbf{1}$ \\
\hline 7 & B-A & $\mathbf{0 . 2 0 9 0 8 3 4 8 7}$ & $\mathbf{6}$ \\
\hline 8 & C-D & $\mathbf{0 . 5 4 2 0 9 2 1 5 8}$ & $\mathbf{5}$ \\
\hline 9 & B-A & $\mathbf{0 . 2 3 9 5 7 7 1 1 8}$ & $\mathbf{5}$ \\
\hline 10 & A-B & $\mathbf{0 . 0 2 0 7 3 2 9 3 9}$ & $\mathbf{1}$ \\
\hline
\end{tabular}

Tabel 5. Simulasi-1: path-node status

\begin{tabular}{ccccc}
\hline $\mathrm{i}$ & path-node & $\forall$ & rand () & status: connected \\
\hline 1 & A-B & 10 & $\mathbf{0 . 0 1 3 5 5 7 4 4 4}$ & no \\
\hline 2 & D-C & 6 & $\mathbf{0 . 7 1 6 9 7 7 0 8 8}$ & yes \\
\hline 3 & E-B & 1 & $\mathbf{0 . 8 6 9 2 4 5 0 7 9}$ & yes \\
\hline 4 & A-D & 10 & $\mathbf{0 . 1 3 8 4 2 3 7 8 3}$ & no \\
\hline 5 & E-B & 9 & $\mathbf{0 . 8 7 2 0 6 7 7 1 6}$ & yes \\
\hline 6 & E-D & 1 & $\mathbf{0 . 9 7 4 2 8 1 3 5 1}$ & yes \\
\hline 7 & B-A & 6 & $\mathbf{0 . 2 0 9 0 8 3 4 8 7}$ & no \\
\hline 8 & C-D & 5 & $\mathbf{0 . 5 4 2 0 9 2 1 5 8}$ & yes \\
\hline 9 & B-A & 5 & $\mathbf{0 . 2 3 9 5 7 7 1 1 8}$ & no \\
\hline 10 & A-B & 1 & $\mathbf{0 . 0 2 0 7 3 2 9 3 9}$ & no
\end{tabular}


Tabel 6. Simulasi-1: posisi node

\begin{tabular}{ccccc}
\hline Node & $x^{\prime}=\operatorname{rand}()$ & $y^{\prime}=\operatorname{rand}()$ & $\mathbf{x}$ & $\mathbf{y}$ \\
\hline A & 0.623081202 & 0.516283127 & $\mathbf{6}$ & $\mathbf{5}$ \\
\hline B & 0.562979782 & 0.078042327 & $\mathbf{6}$ & $\mathbf{1}$ \\
\hline C & 0.745557258 & 0.459036483 & $\mathbf{7}$ & $\mathbf{5}$ \\
\hline D & 0.43056762 & 0.637722112 & $\mathbf{4}$ & $\mathbf{6}$ \\
\hline E & 0.200899001 & 0.718280318 & $\mathbf{2}$ & $\mathbf{7}$ \\
\hline
\end{tabular}

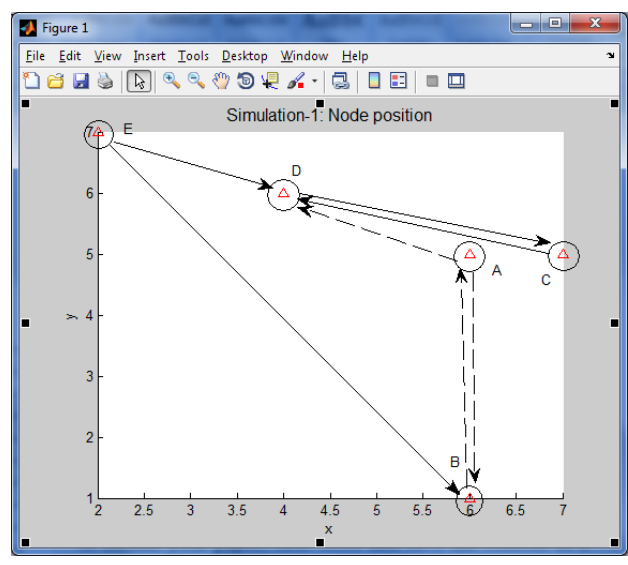

Gambar 3. Skema mobile ad-hoc network pada simulasi-1

Berdasar simulasi-1, routing-network yang terjadi jika node-sender $=\mathrm{E}$ dan node-receiver $=\mathrm{C}$ adalah: E-D-C dengan nilai QoS=7. Namun saat node-sender $=\mathrm{C}$ dan node-receiver $=\mathrm{E}$, routing-network tidak dapat dibangun dengan alasan tidak ada path-node: D-E. Demikian juga berdasar Gambar 3, jika nodesender $=\mathrm{E}$ dan node-receiver $=\mathrm{B}$ maka routing-network yang dipilih adalah: $\mathrm{E}-\mathrm{B}$ dengan $\mathrm{Q}$-S $=9$; tidak melalui node-D. Hal ini disebabkan tidak ada routing yang dapat dibangun dari node-D sebagai sender menuju node tetangga lain ke arah node-B.

Selanjutnya untuk simulasi-2, ditunjukkan pada Tabel-7 sampai dengan 10 memperlihatkan kemunculan berbeda terhadap path-node, nilai QoS dari path-node tersebut beserta status connected-nya. Dan posisi kelima node dalam MANET ditunjukkan pada Gambar 4 yang memperlihatkan routingnetwork yang terbangun beserta kondisi path-node yang mengalami status tersambung atau tidak sama sekali.

Tabel 7. Simulasi-2: path-node

\begin{tabular}{ccc}
\hline $\mathrm{i}$ & rand () & path-node \\
\hline 1 & $\mathbf{0 . 3 9 0 9 7 2 3 3 4}$ & B-E \\
\hline 2 & $\mathbf{0 . 0 6 2 6 6 7 8 6 9}$ & A-C \\
\hline 3 & $\mathbf{0 . 0 0 3 2 1 1 7 7 8}$ & A-B \\
\hline 4 & $\mathbf{0 . 8 3 6 6 7 2 6 1 8}$ & E-A \\
\hline 5 & $\mathbf{0 . 7 1 7 8 0 3 5 8 3}$ & D-C \\
\hline 6 & $\mathbf{0 . 9 8 2 0 1 6 1 4 2}$ & E-D \\
\hline 7 & $\mathbf{0 . 4 9 8 7 7 8 5 7 4}$ & C-B \\
\hline 8 & $\mathbf{0 . 9 0 4 1 8 3 1 1 3}$ & E-C \\
\hline 9 & $\mathbf{0 . 6 9 4 3 7 3 1 9 9}$ & D-B \\
\hline 10 & $\mathbf{0 . 3 5 6 2 2 8 5 1 8}$ & B-E
\end{tabular}

Tabel 8. Simulasi-2: path-cost node

\begin{tabular}{cccc}
\hline i & path-node & $\operatorname{rand}()$ & $\forall$ \\
\hline 1 & B-E & $\mathbf{0 . 5 9 4 1 1 1 9 7 5}$ & $\mathbf{6}$ \\
\hline 2 & A-C & $\mathbf{0 . 4 2 1 6 3 1 8 2 9}$ & $\mathbf{5}$ \\
\hline 3 & A-B & $\mathbf{0 . 3 9 1 7 6 2 6 3 1}$ & $\mathbf{4}$ \\
\hline 4 & E-A & $\mathbf{0 . 6 0 3 7 8 4 9 2 8}$ & $\mathbf{7}$ \\
\hline 5 & D-C & $\mathbf{0 . 9 5 4 4 7 2 5 9 2}$ & $\mathbf{1 0}$ \\
\hline 6 & E-D & $\mathbf{0 . 8 5 5 8 5 1 5 1 5}$ & $\mathbf{9}$ \\
\hline 7 & C-B & $\mathbf{0 . 4 5 5 1 8 2 4 1 2}$ & $\mathbf{5}$ \\
\hline 8 & E-C & $\mathbf{0 . 5 3 2 8 3 7 2 0 5}$ & $\mathbf{6}$ \\
\hline 9 & D-B & $\mathbf{0 . 1 8 1 3 9 5 0 4 1}$ & $\mathbf{2}$ \\
\hline 10 & B-E & $\mathbf{0 . 7 4 7 8 3 5 2 5 8}$ & $\mathbf{8}$ \\
\hline & & &
\end{tabular}


Tabel 9. Simulasi-2: path-node status

\begin{tabular}{ccccc}
\hline i & path-node & $\forall$ & rand () & status: connected \\
\hline 1 & B-E & 6 & $\mathbf{0 . 6 6 8 6 1 8 6 9 6}$ & yes \\
\hline 2 & A-C & 5 & $\mathbf{0 . 8 6 8 1 9 1 5 7 2}$ & yes \\
\hline 3 & A-B & 4 & $\mathbf{0 . 1 4 9 4 6 9 6 7 8}$ & no \\
\hline 4 & E-A & 7 & $\mathbf{0 . 7 2 0 0 1 3 3 4 5}$ & yes \\
\hline 5 & D-C & 10 & $\mathbf{0 . 6 9 4 3 2 3 9 2 1}$ & yes \\
\hline 6 & E-D & 9 & $\mathbf{0 . 4 1 6 5 7 8 2 0 9}$ & no \\
\hline 7 & C-B & 5 & $\mathbf{0 . 8 5 6 1 5 8 8 5 6}$ & yes \\
\hline 8 & E-C & 6 & $\mathbf{0 . 7 4 1 5 7 6 5 8 5}$ & yes \\
\hline 9 & D-B & 2 & $\mathbf{0 . 6 9 4 1 1 0 2 3 8}$ & yes \\
\hline 10 & B-E & 8 & $\mathbf{0 . 1 0 7 2 9 3 8 9 2}$ & no
\end{tabular}

Tabel 10. Simulasi-2: posisi node

\begin{tabular}{ccccc}
\hline Node & $\mathrm{x}^{\prime}=\operatorname{rand}()$ & $\mathrm{y}^{\prime}=\operatorname{rand}()$ & $\mathbf{x}$ & $\mathbf{y}$ \\
\hline A & 0.583794747 & 0.998876056 & $\mathbf{6}$ & $\mathbf{1 0}$ \\
\hline B & 0.404142857 & 0.605286971 & $\mathbf{4}$ & $\mathbf{6}$ \\
\hline C & 0.975184110 & 0.686863299 & $\mathbf{1 0}$ & $\mathbf{7}$ \\
\hline D & 0.299449908 & 0.825399059 & $\mathbf{3}$ & $\mathbf{8}$ \\
\hline E & 0.990745082 & 0.801171870 & $\mathbf{1 0}$ & $\mathbf{8}$ \\
\hline
\end{tabular}

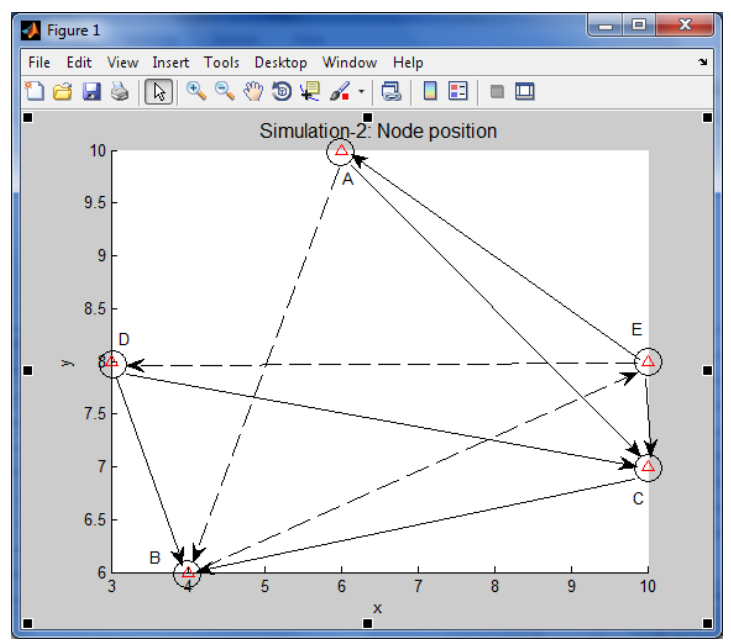

Gambar 4. Skema mobile ad-hoc network pada simulasi-2

Berdasar simulasi-2, routing-network yang terjadi jika node-sender $=\mathrm{E}$ dan node-receiver $=\mathrm{C}$ (jika merujuk pada skenario simulasi-1) adalah: E-C, dan nilai QoS didapatkan 6. Demikian juga, jika kembali merujuk pada simulasi-1, saat node-sender $=\mathrm{C}$ dan node-receiver $=\mathrm{E}$, routing-network tidak dapat dibangun dengan alasan tidak ada path-node: C-E; sehingga disebut: not-available (N/A). Dan berdasar kondisi ini tentunya nilai QoS tidak dapat terukur. Demikian juga berdasar Gambar 4, jika node-sender=E dan node-receiver $=\mathrm{B}$ maka routing-network yang dipilih adalah: E-A-C-B dengan QoS=17.

Selanjutnya untuk simulasi-3 dan 4, agar lebih memperjelas uraian dan tahapan hasil pengujian dilakukan modifikasi kolom dengan tujuan untuk lebih sederhana dan ringkas seperti ditunjukkan pada Tabel 11 sampai dengan 14.

Tabel 11. Simulasi-3: path-node, QoS, dan status

\begin{tabular}{cccc}
\hline i & path-node & $\forall$ & status: connected \\
\hline 1 & E-A & 10 & yes \\
\hline 2 & E-D & 4 & yes \\
\hline 3 & A-B & 5 & no \\
\hline 4 & B-A & 2 & no \\
\hline 5 & B-E & 2 & yes \\
\hline 6 & D-C & 7 & yes \\
\hline 7 & D-C & 4 & yes \\
\hline 8 & E-A & 2 & yes \\
\hline 9 & A-B & 2 & no \\
\hline 10 & A-E & 1 & yes
\end{tabular}


Tabel 12. Simulasi-3: posisi node

\begin{tabular}{ccccc}
\hline node & $\mathrm{x}^{\prime}=\operatorname{rand}()$ & $\mathrm{y}^{\prime}=\operatorname{rand}()$ & $\mathbf{x}$ & $\mathbf{y}$ \\
\hline A & 0.823438389 & 0.866549935 & $\mathbf{8}$ & $\mathbf{9}$ \\
\hline B & 0.659775864 & 0.051527533 & $\mathbf{7}$ & $\mathbf{1}$ \\
\hline C & 0.420010430 & 0.519317952 & $\mathbf{4}$ & $\mathbf{5}$ \\
\hline D & 0.033077146 & 0.832586993 & $\mathbf{0}$ & $\mathbf{8}$ \\
\hline E & 0.280131298 & 0.795783460 & $\mathbf{3}$ & $\mathbf{8}$ \\
\hline
\end{tabular}

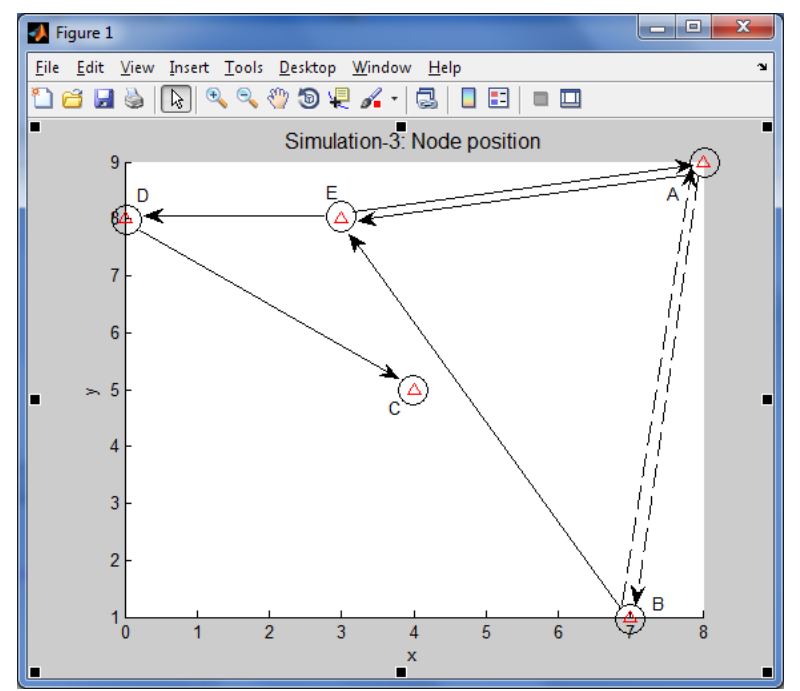

Gambar 5. Skema mobile ad-hoc network pada simulasi-3

Berdasar simulasi-3, routing-network yang terjadi jika node-sender $=\mathrm{E}$ dan node-receiver $=\mathrm{C}$ (jika merujuk pada skenario simulasi-1) adalah diuraikan sebagai berikut:

a) Bandingkan: $\forall(\mathrm{E}, \mathrm{D})$ dan $\forall(\mathrm{E}, \mathrm{A}) \Rightarrow$ pilih nilai terbesar

b) maka: $\forall(\mathrm{E}, \mathrm{D})=4$

c) Oleh sebab tidak ada multi path-node, maka routing-network:

d) $\Rightarrow \forall(\mathrm{D}, \mathrm{C})=4$

e) routing-network: E-D-C dengan QoS terukur pada 8

Namun jika kembali merujuk pada simulasi-1, saat node-sender $=\mathrm{C}$ dan node-receiver $=\mathrm{E}$, routingnetwork tidak dapat dibangun dengan alasan tidak ada path yang dibangun dari node-C sebagai sender; sehingga disebutkan: not-available (N/A). Dan berdasar kondisi ini tentunya nilai QoS tidak dapat terukur. Demikian juga berdasar Gambar 5, jika node-sender=E dan node-receiver $=\mathrm{B}$ maka dapat diuraikan sebagai berikut:

a) Bandingkan: $\forall(\mathrm{E}, \mathrm{D})$ dan $\forall(\mathrm{E}, \mathrm{A}) \Rightarrow$ pilih nilai terbesar maka: $\forall(\mathrm{E}, \mathrm{D})=4$

b) Oleh sebab tidak ada multi-path dari node-D, maka: dipilih $\forall(\mathrm{D}, \mathrm{C})=4$

c) Oleh sebab node-C, sebagai sender, tidak memiliki path-node terhadap node-B, maka routingnetwork tidak dapat dibangun apabila node-E sebagai sender dan node-B sebagai receiver; sehingga alternatif lain dimunculkan dari path-node: E-A, yakni sebagai berikut:

d) Cari: $\forall(\mathrm{E}, \mathrm{A}) \Rightarrow$ didapatkan: 2

e) Bandingkan: $\forall(\mathrm{A}, \mathrm{E})$ dan $\forall(\mathrm{A}, \mathrm{B}) \Rightarrow$ pilih status $=$ connected $\Rightarrow \forall(\mathrm{A}, \mathrm{E})=1$

f) Selanjutnya dipilih: $\forall($ E,D $)=4$

g) Oleh sebab tidak ada multi-path dari node-D, maka: dipilih $\forall(\mathrm{D}, \mathrm{C})=4$

h) Oleh sebab node-C, sebagai sender, tidak memiliki path-node terhadap node- $\mathrm{B}$, maka routingnetwork tidak dapat dibangun apabila node-E sebagai sender dan node-B sebagai receiver

Dengan demikian routing-network tidak dapat dibangun apabila apabila node-E sebagai sender dan node-B sebagai receiver, dan QoS tidak dapat terukur. Hal ini berbeda jika dibandingkan dengan simulasi-1. 
Tabel 13. Simulasi-4: path-node, QoS, dan status

\begin{tabular}{cccc}
\hline i & path-node & $\forall$ & status: connected \\
\hline 1 & B-C & 9 & yes \\
\hline 2 & E-D & 9 & no \\
\hline 3 & D-A & 2 & no \\
\hline 4 & E-D & 2 & yes \\
\hline 5 & B-C & 10 & no \\
\hline 6 & B-E & 7 & yes \\
\hline 7 & E-B & 4 & no \\
\hline 8 & B-A & 4 & no \\
\hline 9 & D-E & 8 & no \\
\hline 10 & C-E & 8 & yes
\end{tabular}

Tabel 14. Simulasi-4: posisi node

\begin{tabular}{ccccc}
\hline Node & $\mathrm{x}^{\prime}=\operatorname{rand}()$ & $\mathrm{y}^{\prime}=\operatorname{rand}()$ & $\mathbf{x}$ & $\mathbf{y}$ \\
\hline A & 0.049469977 & 0.611021086 & $\mathbf{1}$ & $\mathbf{1}$ \\
\hline B & 0.431001650 & 0.213032923 & $\mathbf{4}$ & $\mathbf{5}$ \\
\hline C & 0.188833509 & 0.695460413 & $\mathbf{3}$ & $\mathbf{4}$ \\
\hline D & 0.676516951 & 0.076833047 & $\mathbf{7}$ & $\mathbf{6}$ \\
\hline E & 0.471037214 & 0.790957175 & $\mathbf{9}$ & $\mathbf{1 0}$ \\
\hline
\end{tabular}

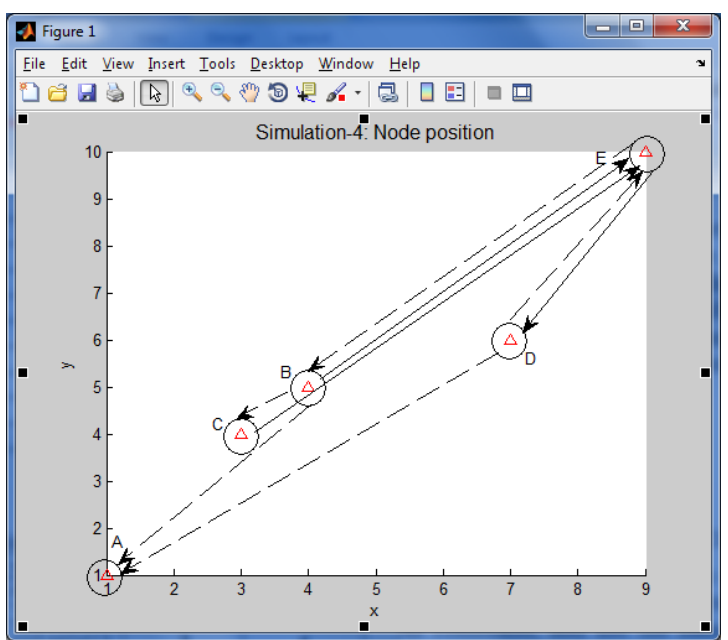

Gambar 6. Skema mobile ad-hoc network pada simulasi-4

Berdasar simulasi-4, routing-network yang terjadi jika node-sender $=\mathrm{E}$ dan node-receiver $=\mathrm{C}$ (jika merujuk pada skenario simulasi-1) adalah: tidak dapat dibangun. Hal ini disebabkan tidak adanya pathnode maupun node-node antar-tetangga yang membangun path-connection dari node-E sebagai sender menuju node-C sebagai receiver; sehingga bisa disebutkan: not-available (N/A). Namun jika kembali merujuk pada simulasi-1, saat node-sender $=\mathrm{C}$ dan node-receiver $=\mathrm{E}$, routing-network dibangun dengan alasan ada path-node: C-E; sehingga QoS terukur dengan nilai 8. Demikian juga berdasar Gambar 6, jika node-sender $=\mathrm{C}$ dan node-receiver $=\mathrm{D}$ maka routing-network yang dipilih adalah: $\mathrm{C}-\mathrm{E}-\mathrm{D}$ dengan $\mathrm{QoS}=8+2=10$.

Dari hasil pengujian ini menunjukkan bahwa setiap simulasi yang dibangkitkan bersifat real-time dan stokastik, sehingga topologi jaringan yang terbentuk memenuhi kriteria dari sebuah jaringan MANET yang bersifat dinamis, fleksibel, dan mengalihfungsikan terminal-client menjadi backwarding/fowardingdevices. Di samping itu juga menunjukkan terpenuhi pergerakan dan perpindahan setiap terminal-client dalam cakupan MANET. Juga terlihat bahwa sebuah terminal-komputer belum tentu bergabung dalam jalinan komunikasi data walaupun terdeteksi dalam kondisi: ON (running).

\section{KESIMPULAN}

Perubahan topologi pada sebaran node-node dalam mobile ad-hoc network merepresentasikan pergerakan node-node tersebut dalam jangkauan line-of-sight sinyal pancar/terima masing-masing client 
host-computer. Dan perubahan topologi tersebut diidentifikasikan dengan perubahan topologi jaringan pada keempat skenario yang telah dilakukan.

Sebuah host-computer dalam jaringan komunikasi data belum tentu teridentifikasi bergabung dalam sinyal pancar/terima pada mobile ad-hoc network, walaupun dalam status ON (running). Demikian juga sebuah host-computer dalam jaringan komunikasi data belum tentu memiliki kanal dengan kondisi QoS yang baik walaupun dalam kondisi ON-LINE, melainkan berada pada hirarki level QoS tertentu.

Dua node yang terjalin pada suatu path-node memiliki weight konektivitas yang bergantung pada parameter end-to-end delay, throughput, dan packet-loss, adalah tidak mengenal sifat komutatif. Hal ini menjelaskan bahwa $\forall_{\mathrm{AB}}$ relatif memiliki nilai identik dengan $\forall_{\mathrm{BA}}$.

Sebuah node dapat memancarkan sinyal ke berbagai node tujuan dan menerima sinyal dari berbagai node saling bertetangga namun tetap mengalami proses antrian untuk masuk ke dalam kondisi prioritas. Dengan demikian jika diupayakan kecepatan pemrosesan pada setiap lapisan TCP/IP dapat ditingkatkan [20], maka secara linier akan memperkecil nilai end-to-end delay dan meningkatkan throughput streaming data.

Mobile Ad-hoc Network terbukti memiliki sifat dan karakteristik topologi yang dinamis, sehingga secara pendekatan kuantatif memiliki installation-cost lebih murah jika dibandingkan dengan conventional wireless network. Di samping itu juga infrastruktur MANET dapat dimanfaatkan untuk kebutuhan monitoring dan identifier object pada suatu area yang bersifat restricted dan protected.

Simulasi dengan menggunakan Algoritma SNetS telah memenuhi kriteria untuk N-node, dimana N menunjukkan jumlah node. Dalam hal ini dapat dideskripsikan ada N topologi MANET yang dapat dibangun secara stokastik dan random, sehingga kondisi memenuhi prasyarat kondisi sebuah lingkungan dan sistem yang mendekati real.

\section{UCAPAN TERIMA KASIH}

Ucapan terima kasih disampaikan kepada Laboratorium Telematika dan Laboratorium Sistem Pengaturan Sekolah Teknik Elektro dan Informatika (STEI) ITB atas dukungan teknis dan infrastrukutur sehingga penelitian ini dapat terselesaikan dengan baik. Demikian juga disampaikan kepada anggota Pusat Studi Telematika dan Kontrol (PUSITELL) Universitas BALE Bandung atas bantuan tenaga dan perangkat saat pengujian dan simulasi dilakukan.

\section{DAFTAR PUSTAKA}

[1] I. Chakeres and C. Perkins, "Dynamic MANET On-Demand (DYMO) Routing," Internet-Draft, draft-ietfmanet-dymo-06.txt, October 2006.

[2] S.N.M.P. Simamora, T.Juhana, Kuspriyanto, N. R. Bagjarasa. "Sistem Pemodelan Perpindahan TerminalUser secara Terpola untuk Mengukur Pola Perubahan Throughput pada Topologi MANET". Seminar Teknologi Informasi dan Sistem Informasi (SeTISI) 2013. Fak. Teknologi Informasi, Univ. Kristen Maranatha, Bandung. pp.186-191. ISBN:978-602-98685-3-1.

[3] S.N.M.P. Simamora, T.Juhana, Kuspriyanto, M. Fajarwati. "Analisis Performa Perpindahan Terminal-Client Menggunakan IPv6 Pada Mobile Ad-Hoc Network". Jurnal Ilmiah Ilmu Komputer Vol.9 No.2 Maret 2013 Fak. Ilmu Komputer, Universitas Pelita Harapan. pp.133-141. ISSN: 1412-9523.

[4] S.N.M.P. Simamora, T.Juhana, Kuspriyanto, N. Setiawan. "IPv6 Addressing Technique based Dynamic Host Configuration Protocol in Mobile Ad-hoc Network", The 7th International Conference on Telecommunication Systems, Services, and Applications (TSSA) 30-31 October 2012, STEI-ITB. Denpasar. Bali. pp:280-283 ISBN: 978-1-4673-4549-1.

[5] S.N.M.P. Simamora, G. W. Wibowo. "Analisis Model Perpindahan Terminal-Client pada W-LAN untuk Layanan Live Radio-Streaming". Seminar Nasional Sistem \& Teknologi Informasi (SNASTI) 2013. STIKOM Surabaya. pp.1-6. ISBN: 978-979-8968-36-5.

[6] S. Basagni, etc. Mobile Ad-Hoc Networking. IEEE-Press. 2004.

[7] S.N.M.P. Simamora, T.Juhana, Kuspriyanto, A. Ruhyani. "The Comparative Analysis of Data-streaming Services for Position Variable in Mobile Ad-hoc Network". Proceedings, SITIA (14th Seminar on Intelligent Technology and Its Applications) 2013. T.Elektro-ITS Surabaya. ISSN:2338-2023.

[8] S.N.M.P. Simamora. "Model Pembelajaran Teknologi Informasi Dengan Teknik MANET Pada Kawasan Tertinggal". Seminar Nasional Indonesia Timur (SENANTI) 2014, PUSKIT, Univ. Atma Jaya Yogyakarta. pp.1-9. ISBN: 978-602-8817-62-2. 
[9] J.M. Hurakadli, S.S. Manvi, J.D. Mallapur."Agent based Connectivity Detection and Routing in Mobile Adhoc Networks". 3rd International IEEE COnference Intelligent Systems. 2006. p.391-395.

[10] S.N.M.P. Simamora. "Dynamics System Modeling Approach in Node Mobility on Mobile Ad-hoc Network". The 1st Conference on Information Technology, Computer, and Electrical Engineering (CITACEE) 2013. Departement of Computer Engineering, Univ. Diponegoro. pp.35-39. ISSN: 2338-5154.

[11] S.N.M.P. Simamora, M. Farid Al Haris, A. Sularsa. "Analisis Kinerja Layanan Voip Pada Jaringan Hotspot Dengan Pendekatan Perpindahan Terminal-Client". Proceeding SNIT (Seminar Nasional Inovasi dan Teknologi) 13 Juni 2012, Univ. BSI. Bandung. pp:21-29. ISBN: 978-602-99213-2-8.

[12] D. Watkins, Craig Scott, "A Graph Alorithm Based Approach To Recovery And Failover In Tactical MANETS". Seventh ACIS International Conference on Software Engineering, Artificial Intelligence, Networking, and Parallel/Distributed Computing. 2006. pp.253-260.

[13] S.N.M.P. Simamora, T.Juhana, Kuspriyanto, A. L. Fajarini. "Pemodelan Graf Dalam Jalur Komunikasi Data Pada Mobile Ad-Hoc Network". Proceeding Of KNSI, 14-15 Februari 2013, STMIK Bumi Gora, Mataram, Indonesia. pp.221-226. ISBN: 978-602-17488-0-0.

[14] W. Wongsason, C. Pirak, R. Mathar. "Adaptive Clustering in MANETs Using Graph Theoretical Algorithms". International Conference on Electrical Engineering/Electronics Computer Telecommunications and Information Technology (ECTI-CON). 2010. pp.789-793.

[15] I. SAU VALLS. "Optimization in Graphs under Degree Constraints Application to Telecommunication Networks". Dissertation, Programa de doctorat en Matematica Aplicada, UNIVERSITAT POLITECN CA DE CATALUNYA. 2009.

[16] V. Ramaiyan. "Topics in Modeling, Analysis and Optimisation of Wireless Networks". THESIS. 2009.

[17] D. Mahrenholz. "Providing QoS for Publish/Subscribe Communication in Dynamic Ad-Hoc Networks". Dissertation. Universitat Magdeburg. 2006.

[18] J.K. Buhagiar, C.J. Debono. "The Application of Discrete Time Methods To Position Estimation in WMANs". IEEE EUROCON 2009. p.1755-1762.

[19] C. Sommer, I. Dietrich, F. Dressler."Realistic Simulation of Network Protocols in VANET Scenarios". IEEE INFOCOM 2008. pp1-5.

[20] S.N.M.P. Simamora. "Analisis Metode Cross-Layer Design dalam Efisiensi Trafik Kanal dengan Pendekatan Teknik Penjadwalan".Seminar Nasional Inovasi dan Rekayasa Teknologi (SNIRT) 2014, Fak. Teknik, Univ. 17 AGustus 1945 Cirebon. hal.95-100. ISSN: 2406-9663. 